\title{
Personalized Medicine in Ocular Fibrosis: Myth or Future Biomarkers
}

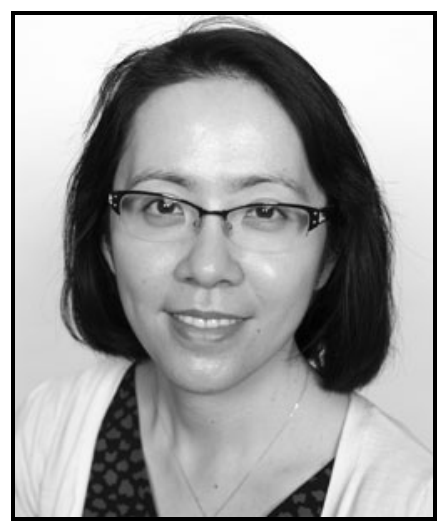

Cynthia Yu-Wai-Man, MBBS, FRCOphth

Submitted for publication October 10, 2015 Accepted in revised form February 4, 2016.

${ }^{*}$ Correspondence: UCL Institute of Ophthalmology, 11-43 Bath Street, London EC1V 9EL, United Kingdom (e-mail: c.yu-wai-man@ucl.ac.uk).

\author{
Cynthia Yu-Wai-Man* and Peng Tee Khaw \\ National Institute for Health Research (NIHR) Biomedical Research Centre at Moorfields Eye Hospital NHS Foundation \\ Trust and UCL Institute of Ophthalmology, London, United Kingdom.
}

Significance: Fibrosis-related events play a part in the pathogenesis or failure of treatment of virtually all the blinding diseases around the world, and also account for over $40 \%$ of all deaths. It is well established that the eye and other tissues of some group of patients, for example Afro-Caribbean people, scar worse than others. However, there is a current lack of reliable biomarkers to stratify the risk of scarring and postsurgical fibrosis in the eye.

Recent Advances: Recent studies using genomics, proteomics, metabolomics, clinical phenotyping, and high-resolution in vivo imaging techniques have revealed potential novel biomarkers to identify and stratify patients at risk of scarring in different fibrotic eye diseases.

Critical Issues: Most of the studies, to date, have been done in animals or small cohorts of patients and future research is needed to validate these results in large longitudinal human studies. Detailed clinical phenotyping and effective biobanking of patient tissues will also be critical for future biomarker research in ocular fibrosis. Future Directions: The ability to predict the risk of scarring and to tailor the antifibrotic treatment regimen to each individual patient will be an extremely useful tool clinically to prevent undertreating, or exposing patients to unnecessary treatments with potential side effects. An exciting future prospect will be to use new advances in genotyping, namely next-generation whole genome sequencing like RNA-Seq, to develop a customized gene chip in ocular fibrosis. Successful translation of future biomarkers to benefit patient care will also ultimately require a strong collaboration between academics, pharmaceutical, and biotech companies.

Keywords: personalized medicine, biomarkers, fibrosis, genotyping, phenotyping

\section{SCOPE AND SIGNIFICANCE}

Fibrosis-Related EVENTS PLAy a part in most of the blinding diseases worldwide (Fig. 1) and also account for over $40 \%$ of all deaths. It is well established that the eye tissues of some group of patients, for example AfroCaribbean people, scar worse than others. However, there is a current lack of reliable biomarkers to stratify the risk of scarring and postsurgical fibrosis in the eye. This review focuses on the recent advances in genomics, proteomics, metabolomics, clinical phenotyping, and high-resolution in vivo imaging techniques that might help to identify and stratify the groups of patients at risk of scarring in different parts of the eye.

\section{TRANSLATIONAL RELEVANCE}

In the next 10 years, the hope is that new advances in genotyping, namely next-generation whole genome

(C) Cynthia Yu-Wai-Man and Peng Tee Khaw, 2016; Published by Mary Ann Liebert, Inc. This Open Access article is distributed under the terms of the Creative Commons License (http://creative commons.org/licenses/by/4.0), which permits unrestricted use, distribution, and reproduction in any medium, provided the original work is properly credited. 


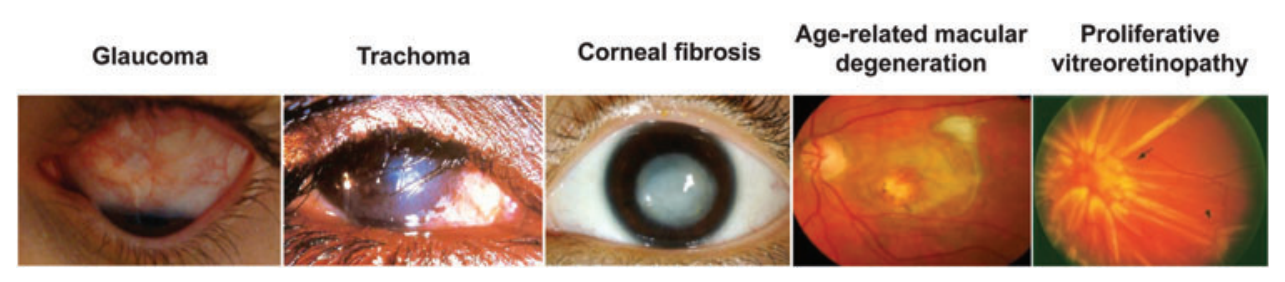

Figure 1. Fibrosis forms part of the pathogenesis or failure of treatment of most blinding diseases worldwide such as glaucoma, trachoma, corneal fibrosis, age-related macular degeneration, and proliferative vitreoretinopathy. To see this illustration in color, the reader is referred to the web version of this article at www.liebertpub.com/wound

sequencing, and detailed clinical phenotyping using modern tissue biomarkers and high-resolution in vivo imaging techniques, will help to identify the groups of patients that would scar more aggressively, and thus help to develop a more personalized and stratified approach in antifibrotic ocular therapeutics. Successful translation of future biomarkers in ocular fibrosis will also ultimately require a strong collaboration between academics, pharmaceutical, and biotech companies.

\section{CLINICAL RELEVANCE}

There is a large unmet clinical need for new predictive and mechanistic biomarkers in ocular fibrosis. Being able to predict patients' risk of scarring and to tailor the antifibrotic treatment regimen to each individual patient will be an extremely useful tool clinically to prevent undertreating, or exposing them to unnecessary treatments with potential side effects. Most of the studies, to date, have been carried out in animals or small cohorts of patients, and future research is thus needed to validate these results in large longitudinal human studies. Detailed clinical phenotyping and effective biobanking of patient tissues will also be critical for future biomarker research in ocular fibrosis.

\section{DISCUSSION}

\section{Tissue genomics}

The NEIBank is a project to gather and organize genomic resources for eye research. ${ }^{1}$ The NEIBank includes expressed sequence tag data and sequenceverified cDNA clones for multiple eye tissues of several species, web-based access to human eyespecific serial analysis of gene expression (SAGE) data through EyeSAGE, and comprehensive annotated databases of known human eye disease genes and candidate disease gene loci. ${ }^{2-5}$

Glaucoma is the commonest cause of irreversible blindness in the world and conjunctival fibrosis is the major determinant of the surgical success after glaucoma filtration surgery (Fig. 2). Popp et al. isolated anterior segment tissues (cornea, conjunctiva, iris) and posterior segment tissues (lens, retina, sclera) of rabbit eyes, and created two independent cDNA libraries through the NEIBank project. ${ }^{6}$ Using microarray analysis, they found the expression of 315 genes to be significantly altered in the rabbit conjunctiva and Tenon's capsule after glaucoma filtration surgery, and these genes included proteins associated with the inflammatory response, defense response, and proteins involved in the synthesis of the extracellular matrix.

Esson et al. also performed a microarray analysis of blebs after glaucoma filtration surgery in Sprague Dawley rats and found a significant treatment effect in 923 genes. $^{7}$ Their results confirmed the expression patterns of known mediators of the bleb scarring process, including transforming growth factor- $\beta$, connective tissue growth factor, matrix metalloproteinases, and structural proteins like collagens.

In addition, Mahale et al. used the human $\mathrm{RT}^{2}$ Profiler polymerase chain reaction (PCR) array to study the differential gene expression between seven capsules of failed Ahmed glaucoma valves and two control Tenon's capsules. ${ }^{8}$ They found 39 genes with more than two-fold differential gene expression in three or more of the capsules, including CTGF, THBS1, SERPINE1, THBS2, COL3A1, $M M P 3$, and $I L 1 A$ genes. Inflammation is a known risk factor for scarring after glaucoma surgery, ${ }^{9}$ and Mahale et al. also found dysregulation of several genes expressing inflammatory cytokines and chemokines (CCL11, IL13, IL1A, IL1B, CXCR4). Their results are supported by the work of Chang et al. who found increased mast cell numbers in the conjunctival tissues of patients with previous glaucoma surgery that might be associated with an increased risk of conjunctival scarring ${ }^{10,11}$ and previous findings that chronic treatment with eyedrops resulted in an increase in inflammatory cells and an increased chance of surgical failure. ${ }^{12,13}$

Conjunctival scarring is also critical following Chlamydia trachomatis infection that leads to trichiasis (inturned eyelids) and painful blindness in trachoma. Burton et al. performed a microarray 
A Human conjunctiva after Glaucoma surgery

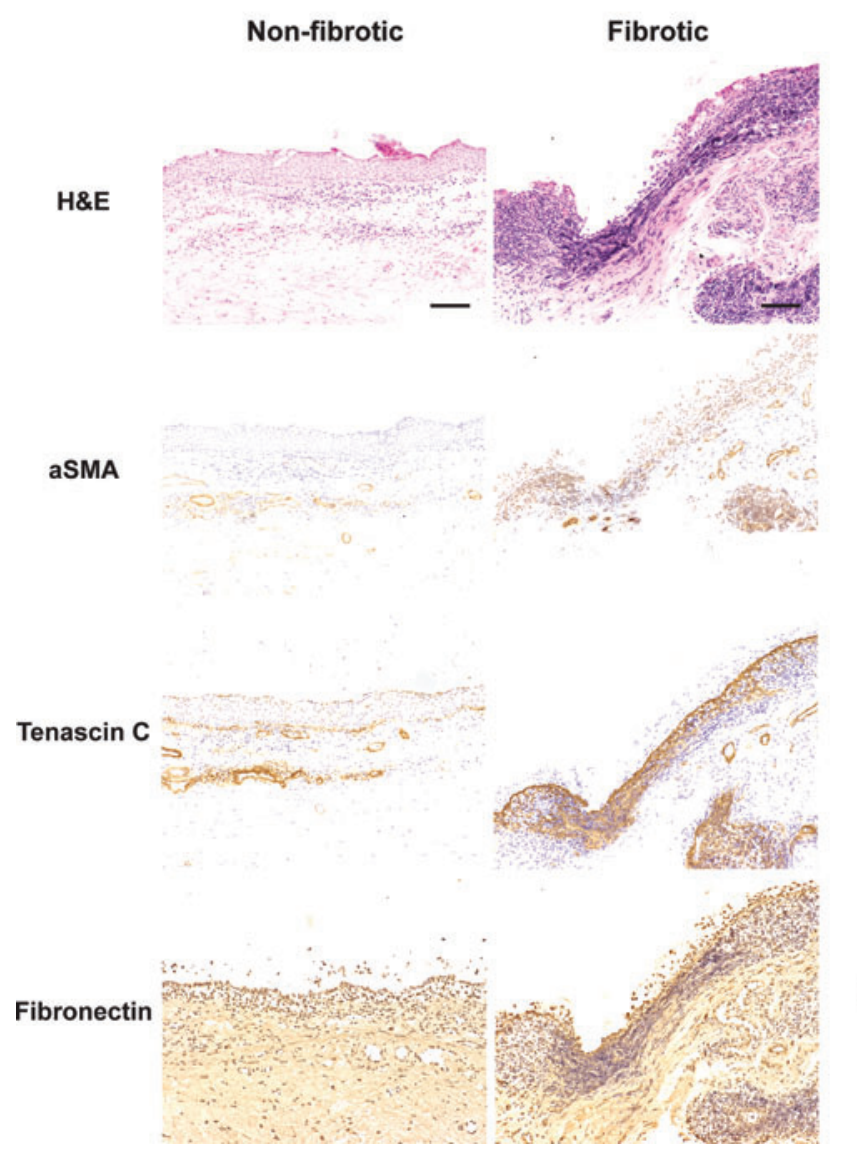

B Rabbit conjunctiva after Glaucoma surgery

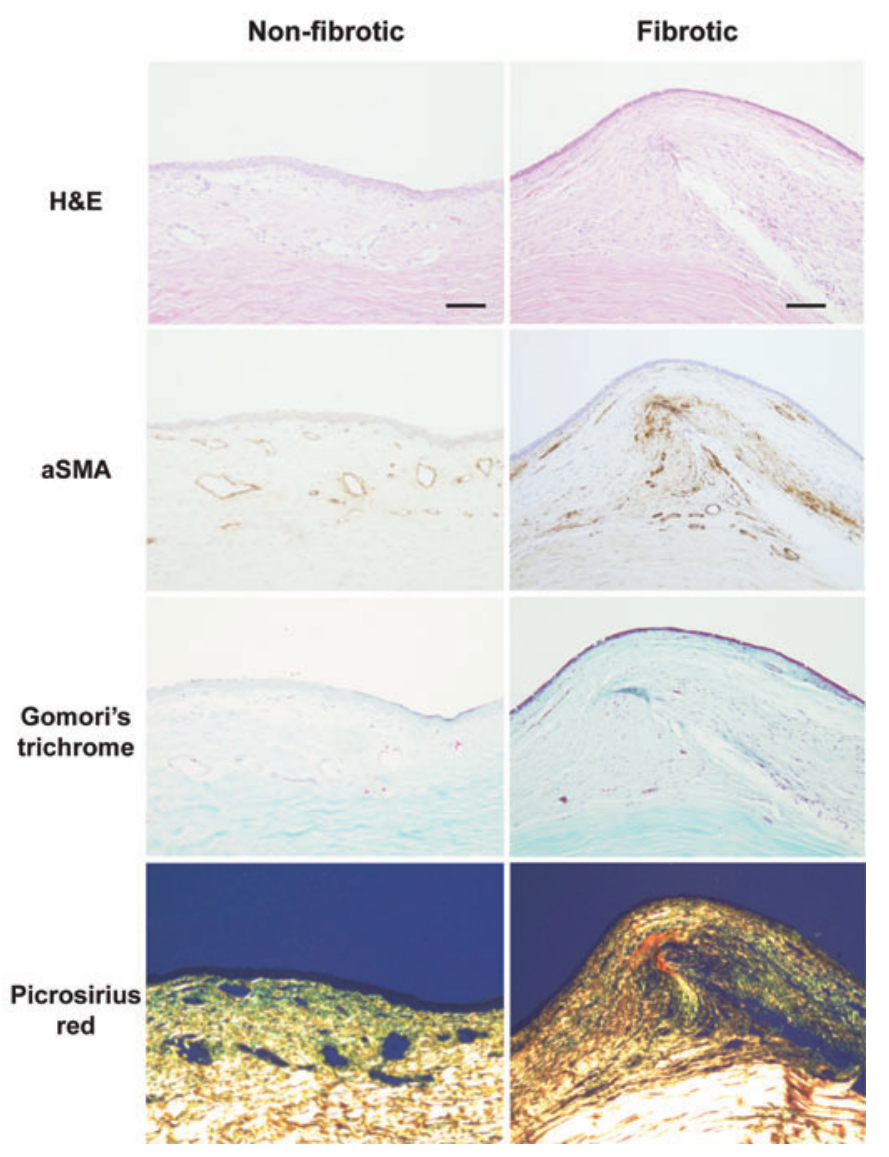

Figure 2. The conjunctiva undergoes marked histopathological changes after glaucoma filtration surgery in (A) humans and (B) a rabbit model of conjunctival fibrosis. There is increased cellularity and $\alpha \mathrm{SMA}$ staining in fibrotic human and rabbit conjunctiva compared to nonfibrotic conjunctiva. Scale bar $=50 \mu \mathrm{m}$. $\alpha \mathrm{SMA}$, alpha smooth muscle actin. To see this illustration in color, the reader is referred to the web version of this article at www.liebertpub.com/wound

analysis on 45 patients with trachomatous trichiasis (TT), as well as real-time quantitative PCR for 16 gene expression targets on 386 TT patients and 386 normal controls. ${ }^{14}$ They found that the gene expression profile of TT patients was consistent with squamous metaplasia (keratins, SPRR), proinflammatory cytokine production (IL1 $\beta, C X C L 5$, $S 100 A 7)$, and tissue remodeling ( $M M P 7, M M P 9$, MMP12, HAS3). Clinical inflammation was associated with increased $S 100 A 7, I L 1 B, I L 17 A, C X C L 5$, CTGF, CEACAM5, MMP7, CD83 and reduced SPARCL1 gene expression. ${ }^{15}$ Burton et al. also reported an increased expression of the $S 100 A 7$ (psoriasin) gene in patients with recurrent TT. ${ }^{16}$

Ocular cicatricial pemphigoid (OCP) is another sight-threatening disease that is associated with severe and chronic conjunctival fibrosis. Razzaque et al. compared conjunctival fibroblasts from 10 OCP patients and 5 normal controls. They found an increased expression of $\mathrm{m}$ - $\mathrm{CSF},{ }^{17} \mathrm{CTGF},{ }^{18} \mathrm{HSP} 47,{ }^{19}$ and macrophage migration inhibitory factor $(M I F)^{20}$ genes in OCP patients using real-time quantitative PCR. Saw et al. also reported an increased expression of interleukin- $13^{21}$ and tumor necrosis factoralpha $^{22}$ in mucous membrane pemphigoid fibroblasts compared to normal human fibroblasts.

Corneal fibrosis is a leading cause of blindness worldwide and can occur after corneal injury, surgery, or secondary to infection (e.g., herpetic keratitis) or inflammation (e.g., pterygium). Varela et al. carried out a microarray analysis on rat corneas after Excimer laser photorefractive keratectomy and identified 73 genes with a three-fold change in expression compared to untreated corneas. ${ }^{23}$ These included genes that play an important role in corneal wound healing, namely growth factors, cell cycle regulators, transcription factors, and metabolic pathway genes.

Using cDNA microarrays, Cao et al. also found the expression of 37 genes to be upregulated and that of 27 genes to be downregulated more than fivefold in healing mouse corneas compared to nor- 
mal uninjured corneas. ${ }^{24}$ The upregulated genes included ICAM-1, macrophage inflammatory proteins, SOCS, IL-10 receptor, and galectin-7. Among the downregulated genes were a gap junction protein (connexin-31), tight junction proteins (ZO1 and occludin), and a key component in the TGF $\beta$ signaling pathway (Smad2).

Moreover, Saravanan et al. analyzed the differential expression of glycosyltransferases in healing mouse corneas using glycogene microarrays. ${ }^{25}$ They found 11 enzymes to be upregulated, namely glycosyltransferases, beta3GalT5, T-synthase, GnTIVb, and 19 enzymes to be downregulated, namely GnTIII and sialyltransferases, in healing mouse corneas compared to normal uninjured corneas.

Retinal fibrosis is the common pathophysiological mechanism in blinding retinal diseases, such as age-related macular degeneration (AMD), diabetic retinopathy, and proliferative vitreoretinopathy (PVR). Using an Affymetrix human genome microarray, Hollborn et al. studied differentially expressed genes between retinas of two PVR patients and seven postmortem normal retinas. ${ }^{26}$ They found upregulation of 80 genes, namely encoding nuclear and cell cycle-related proteins, extracellular secretory proteins, cytosolic signaling proteins, and extracellular matrix proteins. The HGF and heparin-binding EGF-like growth factor genes were also expressed in PVR retinas, but not in control retinas.

In addition, Asato et al. studied the gene expression profile of three eyes with PVR-epiretinal membranes and two eyes with secondary epiretinal membranes. $^{27}$ They found 1116 non-redundant clusters representing individual genes expressed in PVR-epiretinal membranes, and 799 clusters representing the genes expressed in secondary epiretinal membranes. Their results support that PVR-epiretinal membranes represent an aberrant form of the wound healing response in the retina, with an increased expression of genes involved in cell adhesion and proliferation.

There have been several genomic studies to date, but most of them have been carried in animals or small cohorts of patients (Table 1). Future research is thus needed to validate these results in large longitudinal human studies. One of the major hurdles has been the lack of availability of human tissues for biomarker research. Effective detailed clinical phenotyping and biobanking of large cohorts of patients will therefore be crucial to study putative biomarkers in fibrotic eye diseases compared to healthy controls. Another exciting prospect in the future will be to use new advances in genomics, namely next-generation whole genome sequencing like RNA-Seq, to develop a customized gene chip in ocular fibrosis.

\section{Serum and tear biomarkers}

As tissue biopsy can lead to scarring, serum and tear biomarkers represent a less invasive alternative to tissue biopsy in fibrosis (Table 1). The enhanced liver fibrosis (ELF) test is a clinical-grade serum test that could be used as a biomarker of overall fibrosis in liver fibrosis ${ }^{28}$ and systemic sclerosis. ${ }^{29}$ FibroMeters are blood tests that display a high overall diagnostic accuracy in staging and quantification of liver fibrosis, and are useful for patient follow-up. ${ }^{30}$ The serum levels of miR29a are also significantly associated with patients with liver fibrosis, ${ }^{31}$ and hypertrophy and fibrosis in patients with hypertrophic cardiomyopathy. ${ }^{32}$

For the anterior segment of the eye, Tezel et al. used liquid chromatography and linear ion trap mass spectrometry to compare the sera of 111 patients with primary open-angle glaucoma (POAG) and 49 healthy controls. ${ }^{33}$ They found 106 proteins to be increased in the glaucomatous sera and 63 proteins to be present in only the glaucomatous sera. They validated their results and identified four molecules (apoptosis-inducing factor, CREBbinding protein, ephrin type-A receptor, huntingtin protein) with higher serum enzyme-linked immunosorbent assay titers in the POAG patients. Chong et al. also determined the tear cytokine profile using a multiplex bead assay in 61 glaucoma patients and 29 normal subjects, and found that the eyes at risk of scarring in the early postoperative period had significantly increased MCP-1 level. ${ }^{34}$

Serum biomarkers have been studied in more detail for the posterior segment of the eye, namely following laser-induced retinal injuries. Dunmire et al. used liquid chromatography-tandem mass spectrometry and found 19 proteins to be significantly increased in the sera of Rhesus macaques after laser-induced retinal injury. ${ }^{35}$ Four proteins (phosphoglycerate kinase 1, keratin 18, Lewis alpha-3-fucosyltransferase, and ephrin receptor A2) showed significant differences at both 4 hours and 1 day after laser injury, followed by a decrease to baseline levels by the third day. Scott et al. also identified four autoantigens in the sera of rabbits after minimally invasive and grade II laser-induced retinal injuries using liquid chromatography/tandem mass spectrometry. ${ }^{36}$ The four candidate autoantigens were dihydropyrimidinaserelated protein 2 , fructose-bisphosphate aldolase $\mathrm{C}$, chaperonin-containing T-complex polypeptide 1 subunit zeta, and pyruvate kinase isozyme. 
Table 1. Potential novel biomarkers in ocular fibrosis and wound healing

\begin{tabular}{|c|c|c|c|c|}
\hline Biomarkers & References & Techniques & Species and Tissues & Results \\
\hline \multirow[t]{11}{*}{ Tissue genomics } & Popp et al. ${ }^{6}$ & Microarray & $\begin{array}{l}\text { Rabbit conjunctiva and Tenon's } \\
\text { capsules after GFS }\end{array}$ & $\begin{array}{l}315 \text { genes, namely encoding serum amyloid A-3 } \\
\text { protein, IL-1 beta, alpha-1-acid glycoprotein, } \\
\text { cathepsin K, MMP-9, neutrophil granules matrix } \\
\text { glycoprotein SGP28, ceruloplasmin, lumican, Iyso- } \\
\text { zyme C, and fibronectin }\end{array}$ \\
\hline & Esson et al. ${ }^{7}$ & Microarray & Rat blebs after GFS & $\begin{array}{l}923 \text { genes, namely encoding TGF } \beta \text {, CTGF, FGF, IGF, } \\
\text { matrix metalloproteinases, collagens, vimentin, } \\
\text { and fibronectin }\end{array}$ \\
\hline & Mahale et al. ${ }^{8}$ & $\mathrm{RT}^{2}$ Profiler PCR Array & $\begin{array}{l}7 \text { human Tenon's capsules of } \\
\text { failed Ahmed valves }\end{array}$ & $\begin{array}{l}39 \text { genes, including CTGF, THBS1, SERPINE1, THBS2, } \\
\text { COL3A1, MMP3, and IL1A genes }\end{array}$ \\
\hline & Varela et $a l^{23}$ & Microarray & Rat corneas after Excimer PRK & $\begin{array}{l}73 \text { genes, including growth factors (VEGF, FGF, IGF- }- \text {, } \\
\text { proteases (PAI-1, PAI-2A), and protease inhibitors } \\
\text { (TIMP-2, TIMP-3) }\end{array}$ \\
\hline & \multirow[t]{2}{*}{ Burton et al. ${ }^{14,15}$} & Microarray & $\begin{array}{l}45 \text { trachomatous trichiasis } \\
\text { patients }\end{array}$ & \multirow{3}{*}{$\begin{array}{l}\text { Squamous metaplasia (keratins, SPRR), proinflam- } \\
\text { matory cytokine production (IL1 } 1 \beta, C X C L 5, \text { S100A7), } \\
\text { and tissue remodeling (MMP7, MMPG, MMP12, } \\
\text { and HAS3) } \\
\text { Upregulated } m \text {-CSF, CTGF, HSP47, and MIF genes }\end{array}$} \\
\hline & & Real-time quantitative PCR & $\begin{array}{l}386 \text { trachomatous trichiasis } \\
\text { patients }\end{array}$ & \\
\hline & Razzaque et al. ${ }^{17-20}$ & Real-time quantitative PCR & $\begin{array}{l}10 \text { patients with ocular cicatricial } \\
\text { pemphigoid }\end{array}$ & \\
\hline & Cao et al. ${ }^{24}$ & cDNA microarrays & Healing mouse corneas & $\begin{array}{l}37 \text { genes upregulated and } 27 \text { genes downregulated, } \\
\text { namely encoding ICAM-1, macrophage inflamma- } \\
\text { tory proteins, SOCS, IL-10 receptor, galectin-7, } \\
\text { connexin-31, Z01 and occludin, and Smad2 }\end{array}$ \\
\hline & Saravanan et al..$^{25}$ & Glycogene microarrays & Healing mouse corneas & $\begin{array}{l}11 \text { enzymes upregulated and } 19 \text { enzymes down- } \\
\text { regulated, including glycosyltransferases, beta3- } \\
\text { GalT5, T-synthase, GnTIVb, GnTIII, and } \\
\text { sialyltransferases }\end{array}$ \\
\hline & Hollborn et al. ${ }^{26}$ & $\begin{array}{l}\text { Affymetrix human genome } \\
\text { microarray }\end{array}$ & 2 human retinas of PVR patients & $\begin{array}{l}80 \text { genes upregulated, namely encoding nuclear and } \\
\text { cell cycle related, extracellular secretory, cytosolic } \\
\text { signaling, and extracellular matrix proteins, HGF, } \\
\text { and HB-EGF }\end{array}$ \\
\hline & Asato et al..$^{27}$ & PCR-amplified cDNA library & $\begin{array}{l}3 \text { human eyes with PVR-epiretinal } \\
\text { membranes }\end{array}$ & $\begin{array}{l}1116 \text { gene clusters, namely related to metabolism, } \\
\text { cell adhesion, cytoskeleton, and signaling }\end{array}$ \\
\hline \multirow[t]{5}{*}{$\begin{array}{l}\text { Serum and tear } \\
\text { biomarkers }\end{array}$} & Tezel et al..$^{33}$ & Linear ion trap mass spectrometry & 111 patients with POAG & $\begin{array}{l}63 \text { proteins, including AIF, CREB-binding protein, } \\
\text { ephrin type-A receptor, and huntingtin protein }\end{array}$ \\
\hline & Chong et $a l^{34}$ & $\begin{array}{l}\text { Tear cytokine profile using } \\
\text { multiplex bead assay }\end{array}$ & 61 glaucoma patients & Increased MCP-1 level \\
\hline & Dunmire et $a l_{.}^{35}$ & $\begin{array}{l}\text { Liquid chromatography- } \\
\text { Mass spectrometry }\end{array}$ & $\begin{array}{l}\text { Rhesus macaques sera after } \\
\text { laser-induced retinal injury }\end{array}$ & $\begin{array}{l}19 \text { proteins, including phosphoglycerate kinase } 1 \text {, } \\
\text { keratin } 18 \text {, Lewis alpha-3-fucosyltransferase, and } \\
\text { ephrin receptor A2 }\end{array}$ \\
\hline & Scott et al. ${ }^{36}$ & $\begin{array}{l}\text { Liquid chromatography- } \\
\text { Mass spectrometry }\end{array}$ & $\begin{array}{l}\text { Rabbit sera after laser-induced } \\
\text { retinal injury }\end{array}$ & $\begin{array}{l}4 \text { candidate autoantigens, namely } \\
\text { dihydropyrimidinase-related protein 2, fructose- } \\
\text { bisphosphate aldolase C, chaperonin-containing T- } \\
\text { complex polypeptide } 1 \text { subunit zeta, and pyruvate } \\
\text { kinase isozyme }\end{array}$ \\
\hline & Kierny et al. ${ }^{37}$ & Mass spectrometry, phage-display & $\begin{array}{l}\text { Rabbit sera after laser-induced } \\
\text { retinal injury }\end{array}$ & $\begin{array}{l}\text { Antibodies against } 4 \text { peptides derived from putative } \\
\text { biomarkers; GBB5 retinal protein }\end{array}$ \\
\hline \multirow[t]{3}{*}{ Proteomics } & Saccà et al. ${ }^{42}$ & Antibody microarray method & $\begin{array}{l}\text { Aqueous humour of } 14 \text { POAG } \\
\text { patients }\end{array}$ & $\begin{array}{l}13 \text { proteins, including apolipoprotein } \mathrm{B} \text {, apolipopro- } \\
\text { tein } \mathrm{E} \text {, vasodilator-stimulated phosphoprotein, } \\
\text { heat shock } 60 \mathrm{kDa} \text { protein, heat shock } 90 \mathrm{kDa} \\
\text { protein, myogenin, myogenic factor } 3 \text {, myotrophin, } \\
\text { ankyrin, ubiquitin fusion degradation } 1 \text {-like, phos- } \\
\text { pholipase } \mathrm{C} \text { beta } 1 \text {, phospholipase } \mathrm{C} \text { gamma } 1 \text {, } \\
\text { and albumin }\end{array}$ \\
\hline & Anshu et al. ${ }^{43}$ & $\begin{array}{l}\text { Liquid chromatography- } \\
\text { Mass spectrometry }\end{array}$ & $\begin{array}{l}\text { Aqueous humour of } 11 \text { patients } \\
\text { with glaucoma tube implants }\end{array}$ & $\begin{array}{l}13 \text { proteins, including gelsolin, plasminogen, angio- } \\
\text { tensinogen, apolipoprotein A-II, beta-2- } \\
\text { microglobulin, dickkopf-3, pigment epithelium- } \\
\text { derived factor, RIG-like 7-1, afamin, fibronectin 1, } \\
\text { apolipoprotein A-I, activated complement C4 pro- } \\
\text { tein, and prothrombin }\end{array}$ \\
\hline & Rosenfeld et al. ${ }^{44}$ & $\begin{array}{l}\text { Liquid chromatography- } \\
\text { Mass spectrometry }\end{array}$ & $\begin{array}{l}\text { Aqueous humour of } 20 \text { patients } \\
\text { with glaucoma implants }\end{array}$ & 718 proteins, splice variants or isoforms \\
\hline
\end{tabular}


Table 1. (Continued)

\begin{tabular}{|c|c|c|c|c|}
\hline Biomarkers & References & Techniques & Species and Tissues & Results \\
\hline & Yu et al. ${ }^{46}$ & Mass spectrometry & $\begin{array}{l}24 \text { human vitreous samples from } \\
\text { RRD patients with PVR }\end{array}$ & $\begin{array}{l}\text { Upregulated alpha2-HS-glycoprotein, alpha1B- } \\
\text { glycoprotein, complement components, and he- } \\
\text { mopexin; Downregulated opticin precursors and } \\
\text { actin family members }\end{array}$ \\
\hline & Yu et al..$^{47}$ & $\begin{array}{l}\text { Liquid chromatography- } \\
\text { Mass spectrometry }\end{array}$ & 24 PVR patients with RRD & $\begin{array}{l}\text { Upregulated transferrin, albumin precursor, alpha2- } \\
\text { HS-glycoprotein, alpha1B-glycoprotein, serpins } \\
\text { family, and complement components; Downregu- } \\
\text { lated tubulin, pyruvate kinase 3, enolase, and } \\
\text { GAPDH }\end{array}$ \\
\hline \multirow[t]{3}{*}{ Metabolomics } & Karamichos et al..$^{52}$ & Mass spectrometry & Human keratoconus cell lines & $\begin{array}{l}\text { Elevated lactate levels, lactate/malate, and lactate/ } \\
\text { pyruvate ratios; Reduced arginine levels and } \\
\text { glutathione/oxidized glutathione ratio }\end{array}$ \\
\hline & Osborn et al. ${ }^{55}$ & $\begin{array}{l}\text { Liquid chromatography- } \\
\text { Mass spectrometry }\end{array}$ & $\begin{array}{l}26 \text { patients with neovascular AMD } \\
\text { and fibrovascular tissue }\end{array}$ & $\begin{array}{l}94 \text { metabolic features, namely acetylphenylalanine, } \\
\text { glycocholic acid, vitamin D-related metabolites, } \\
\text { phenylalanine, tyrosine, glutamine, and aspartate }\end{array}$ \\
\hline & $\begin{array}{l}\text { Agudo-Barriuso } \\
\text { et al. }{ }^{56}\end{array}$ & Mass spectrometry & Rat optic nerve injury & $\begin{array}{l}27 \text { metabolites (between control and } 14 \text { days) and } 36 \\
\text { metabolites (between } 24 \mathrm{~h} \text { and } 14 \text { days), linked to } \\
\text { translation, oxidative stress, glucose and tricar- } \\
\text { boxylic acid cycle and apoptosis }\end{array}$ \\
\hline \multirow[t]{2}{*}{$\begin{array}{l}\text { Clinical } \\
\text { phenotyping }\end{array}$} & $\begin{array}{l}\text { Kon et al. }{ }^{57} \\
\text { Asaria et al. }\end{array}$ & $\begin{array}{l}\text { Univariate and multivariate } \\
\text { logistic regression analysis }\end{array}$ & $\begin{array}{l}140 \text { patients having a primary } \\
\text { vitrectomy for rhegmatogenous } \\
\text { retinal detachment }\end{array}$ & $\begin{array}{l}\text { Risk factors for PVR: Preoperative PVR, aphakia, and } \\
\text { high vitreous protein levels }\end{array}$ \\
\hline & Rajak et al. ${ }^{59}$ & Logistic regression analysis & $\begin{array}{l}1300 \text { patients with trachomatous } \\
\text { trichiasis in Ethiopia }\end{array}$ & $\begin{array}{l}\text { Risk factors for recurrence: Preoperative major } \\
\text { trachomatous trichiasis (>5 trichiatic lashes), } \\
\text { preoperative entropic lashes compared to misdir- } \\
\text { ected/metaplastic lashes, and age over } 40 \text { years }\end{array}$ \\
\hline \multirow{4}{*}{$\begin{array}{l}\text { Noninvasive } \\
\text { Imaging }\end{array}$} & Singh et al. ${ }^{71,72}$ & Anterior segment OCT & 78 filtering blebs in 55 patients & $\begin{array}{l}\text { Successful blebs displayed thickening of the bleb } \\
\text { wall }\end{array}$ \\
\hline & Siriwardena et al. ${ }^{73}$ & Laser flare meter & 131 trabeculectomy patients & Increased anterior chamber flare and inflammation \\
\hline & Wolff et al. ${ }^{75}$ & Spectral domain OCT & 15 eyes with neovascular AMD & $\begin{array}{l}\text { Branching retinal tubulation network emanating from } \\
\text { a fibrovascular scar }\end{array}$ \\
\hline & Coscas et al..$^{76}$ & Spectral domain OCT & 38 patients with fibrovascular PED & $\begin{array}{l}\text { Homogeneous hyperreflectivity consistent with } \\
\text { fibrous tissue }\end{array}$ \\
\hline
\end{tabular}

GFS, glaucoma filtration surgery; PCR, polymerase chain reaction; PVR, proliferative vitreoretinopathy; POAG, primary open-angle glaucoma; RRD, rhegmatogenous retinal detachment; AMD, age-related macular degeneration; OCT, optical coherence tomography; PED, pigment epithelial detachment.

In addition, Kierny et al. generated recombinant antibodies against putative biomarkers of retinal injury in rabbit sera following laser-induced retinal injury. ${ }^{37}$ They generated single-chain variable fragment antibodies against four peptides derived from putative biomarkers of laser-induced retinal injury using phage display. One antibody against the retinal protein, guanine nucleotide-binding protein beta 5 (GBB5), was carried further to demonstrate a method to characterize antibodies generated from peptide fragments identified by mass spectrometry of serum samples.

\section{Proteomics}

Proteomics is gaining increasing interest in the field of eye research due to recent advances in protein chemistry, mass spectrometry, and bioinformatics $^{38}$ (Table 1). Several groups are developing potential proteomic biomarkers in idiopathic pulmonary fibrosis ${ }^{39}$ and liver fibrosis. ${ }^{40,41}$ In the 
eye, Saccà et al. compared the aqueous humour proteome of 14 POAG patients to that of normal controls using the antibody microarray method. ${ }^{42}$ They found the levels of 13 proteins to be significantly increased in the aqueous humour of POAG patients. These proteins are involved in inflammation, delivery of cholesterol to cells, muscle cell differentiation, stress response, and signal transduction, and might reflect the damage occurring to the trabecular meshwork and to the anterior chamber endothelia in glaucoma.

Anshu et al. also identified 13 proteins to be significantly higher in the aqueous humour of $11 \mathrm{pa}-$ tients with a glaucoma tube implant using liquid chromatography-mass spectrometry. ${ }^{43}$ These proteins play a role in oxidative stress, apoptosis, inflammation, and immunity, and their presence in the aqueous humour suggests that glaucoma tube implants cause either a breach in the blood-aqueous barrier or chronic trauma, increasing the influx of oxidative, apoptotic, and inflammatory proteins. In addition, Rosenfeld et al. studied the aqueous humour of 20 patients with different glaucoma operations. ${ }^{44}$ They found the aqueous humour protein concentrations to be ten-fold in the Ahmed and Baerveldt eyes and five-fold in the trabeculectomy and Ex-PRESS eyes. They also identified 718 unique proteins, splice variants or isoforms using liquid chromatography-tandem mass spectrometry.

Retinal detachment leads to cellular remodeling of the retina. Mandal et al. reported that 18 proteins were differentially expressed between detached rabbit retina and controls using liquid chromatography-tandem mass spectrometry. ${ }^{45}$ The proteins identified were involved in a wide range of processes, including cell metabolism, cell structure, mitochondrial function, and phototransduction, and might play an important role in the wound response of the retina after its detachment and its subsequent ability to recover following surgical reattachment.

Using sodium dodecyl sulfate-polyacrylamide gel electrophoresis and reverse-phase liquid chromatography-tandem mass spectrometry, Yu et al. also found 48 overlapping proteins in the vitreous of 24 patients with rhegmatogenous retinal detachment (RRD) and PVR. ${ }^{46}$ The authors used GeneGo MetaCore (Version 6.6; GeneGo, Carlsbad, CA) for the enrichment flow analysis. They found inflammation to be an important GeneGo network and identified the complement and coagulation cascade as the essential pathway. Yu et al. also carried out a vitreous proteomic analysis in $24 \mathrm{PVR}$ patients with RRD using two-dimensional nano liquid chromatography coupled with tandem mass spectrometry. ${ }^{47}$ They identified 102 PVR-specific proteins and proposed that kininogen 1 could become a potential candidate biomarker as it was specifically detected in both the vitreous and corresponding serum samples.

\section{Metabolomics}

Metabolomics is a relatively new technology that measures the set of metabolites that make up the metabolome of a cell or tissue,${ }^{48}$ and there has been growing interest in using metabolomics to identify clinically relevant biomarkers ${ }^{49}$ (Table 1). Several metabolic products have been reported as biomarkers of fibrosis in nonalcoholic fatty liver disease. ${ }^{50}$ Alterations in metabolic pathways have also been reported in idiopathic pulmonary fibrosis and measurement of these metabolites could be used as future diagnostic and prognostic biomarkers. ${ }^{51}$

Keratoconus is a corneal ectasia that is associated with corneal scarring, and altered cellular metabolism has been linked to promoting the fibrotic phenotype and scarring in the cornea. Karamichos et al. identified that several of the metabolic pathways that were significantly different between human keratoconus cells and human corneal keratocytes were related to oxidative stress, and that human keratoconus cells expressed elevated lactate levels, lactate/malate and lactate/pyruvate ratios, and reduced arginine levels and glutathione/oxidized glutathione ratio. ${ }^{52}$

PVR is the major cause of failure of retinal detachment surgery and is caused by contraction of fibrotic membranes on the epiretinal surface of the neurosensory retina. ${ }^{53}$ Using reversed-phase liquid chromatography-quadrupole time-of-flight mass spectrometry, Li et al. identified 31 metabolites as potential biomarkers in 17 vitreous samples of PVR patients. ${ }^{54}$ Inflammation, proliferation, and energy consumption were the three major disturbed biological processes involved in PVR development.

Osborn et al. also performed a metabolome-wide association study of 26 patients with neovascular AMD and fibrovascular tissue using liquid chromatography and Fourier transform mass spectrometry. ${ }^{55}$ They found 94 unique metabolic features to be significantly different between patients with neovascular AMD and fibrovascular tissue compared to healthy controls.

In addition, Agudo-Barriuso et al. identified 27 metabolites to discriminate between control and 14 days after rat optic nerve injury, using gas chromatography/mass spectrometry and liquid chromatography/mass spectrometry techniques. ${ }^{56}$ Enrichment analysis showed alterations in the amino acid, carbohydrate, and lipid metabolism that were further linked to translation, oxidative 
stress, energy (glucose and tricarboxylic acid cycle), and apoptosis through ceramide pathways.

\section{Clinical phenotyping}

Clinical phenotyping is another critical aspect of personalized medicine and several groups have studied potential clinical models to predict the risk of scarring and fibrosis in the eye (Fig. 3 and Table 1). Kon et al. carried out a univariate and multivariate logistic regression analysis on 140 patients with RRD. ${ }^{57}$ They found that the significant risk factors associated with the development of PVR were preoperative PVR, aphakia, and high vitreous protein levels. The authors also constructed two statistical models (clinical factors only and clinical factors combined with vitreous protein level) to predict the probability of developing postoperative PVR and to identify the high-risk patients that might benefit from pharmacological antifibrotic therapies. ${ }^{57,58}$

Moreover, trachoma is the most common infectious cause of blindness worldwide and causes trichiasis, leading to conjunctival scarring and visual loss. Lid rotation surgery is the mainstay of treatment for TT, but the risk of recurrence is high. Rajak et al. carried out a 2-year follow-up study of

A Moorfields Bleb Grading

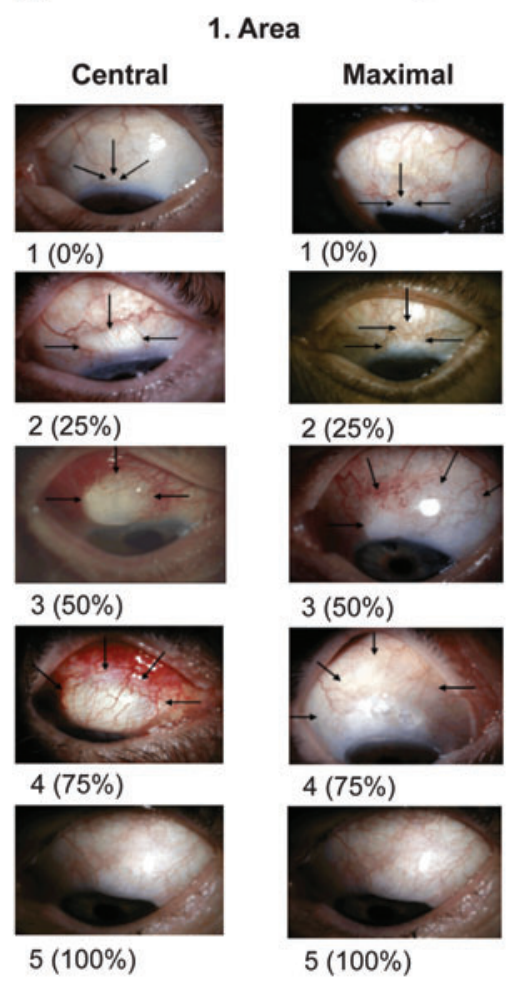

2. Height

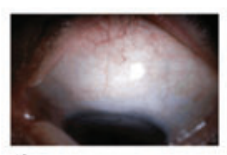

1

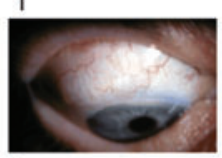

2

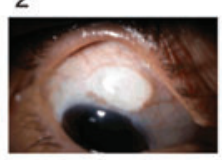

3

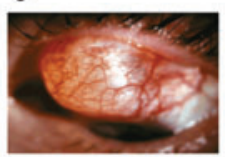

4
3. Vascularity

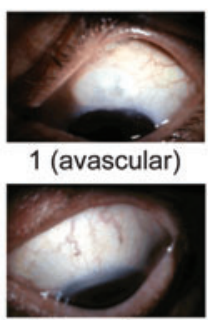

2 (normal)

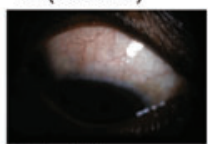

3 (mild)

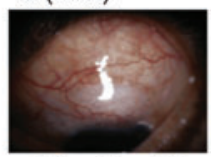

4 (moderate)

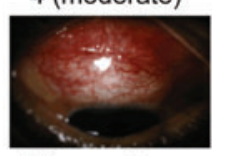

5 (severe)

\section{B Proliferative Vitreoretinopathy Grading}
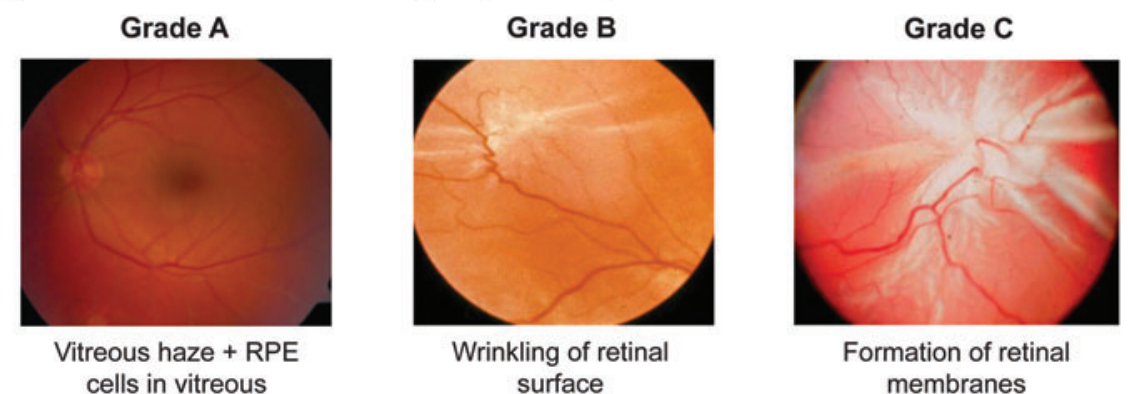

Formation of retinal membranes

Figure 3. Detailed clinical phenotyping of patients alongside effective biobanking of tissues from large patient cohorts will be critical for future biomarker research in ocular fibrosis. (A) Glaucoma blebs are graded with respect to area [scale 1-5], height [scale 1-4], and vascularity [scale 1-5]. (B) The severity of proliferative vitreoretinopathy is graded as Grade A [vitreous haze and RPE cells in vitreous], Grade B [wrinkling of the edges of the retinal tear or inner retinal surface], or Grade C [formation of retinal membranes]. To see this illustration in color, the reader is referred to the web version of this article at www.liebertpub.com/wound 
1300 patients with TT in Ethiopia. ${ }^{59}$ The authors found that recurrence was associated with specific clinical features such as major TT preoperatively ( $>5$ trichiatic lashes), preoperative entropic lashes compared to misdirected/metaplastic lashes, and age over 40 years.

\section{Noninvasive imaging}

High-resolution real-time in vivo imaging represents a promising new technique to help stratify patients in fibrosis and wound healing (Fig. 4 and Table 1). Positron Emission Tomography (PET) is a functional noninvasive imaging technique, whereby the concentration of the biologically active tracer, fluorodeoxyglucose, corresponds to tissue metabolic activity. Several research groups have studied the use of PET scans to monitor idiopathic lung fibrosis, ${ }^{60}$ retroperitoneal fibrosis, ${ }^{61}$ and myelofibrosis. ${ }^{62}$ FibroScan is also an ultrasoundbased transient elastography technique and is currently the most reliable noninvasive method to assess liver stiffness and fibrosis, as an alternative to liver biopsy. ${ }^{63,64}$
In the eye, several groups have shown that highresolution, high-contrast second-harmonic generation imaging provides a sensitive means to detect corneal fibrosis after excimer laser surface ablation and corneal injury. ${ }^{65-67}$ The corneal wound was associated with high cell density and alignment of intracellular actin filaments with collagen fiber bundles, ${ }^{65}$ and irregularly arranged collagen fibers. ${ }^{67}$ The authors thus suggested that highresolution in vivo imaging could be used in the future to assess the effects of antifibrotic therapy on corneal wound healing after refractive surgery or corneal injury.

Simple image grading, particularly of redness indicating inflammation, is a very good indicator of impending failure of glaucoma filtration surgery. ${ }^{68}$ Other research groups have also investigated the use of anterior segment optical coherence tomography (AS-OCT) to predict the surgical failure and scarring after glaucoma drainage surgery. ${ }^{69-72} \mathrm{AS}$ OCT was used to assess different bleb characteristics, including total bleb height, bleb cavity, bleb wall thickness, scleral flap thickness, and patency

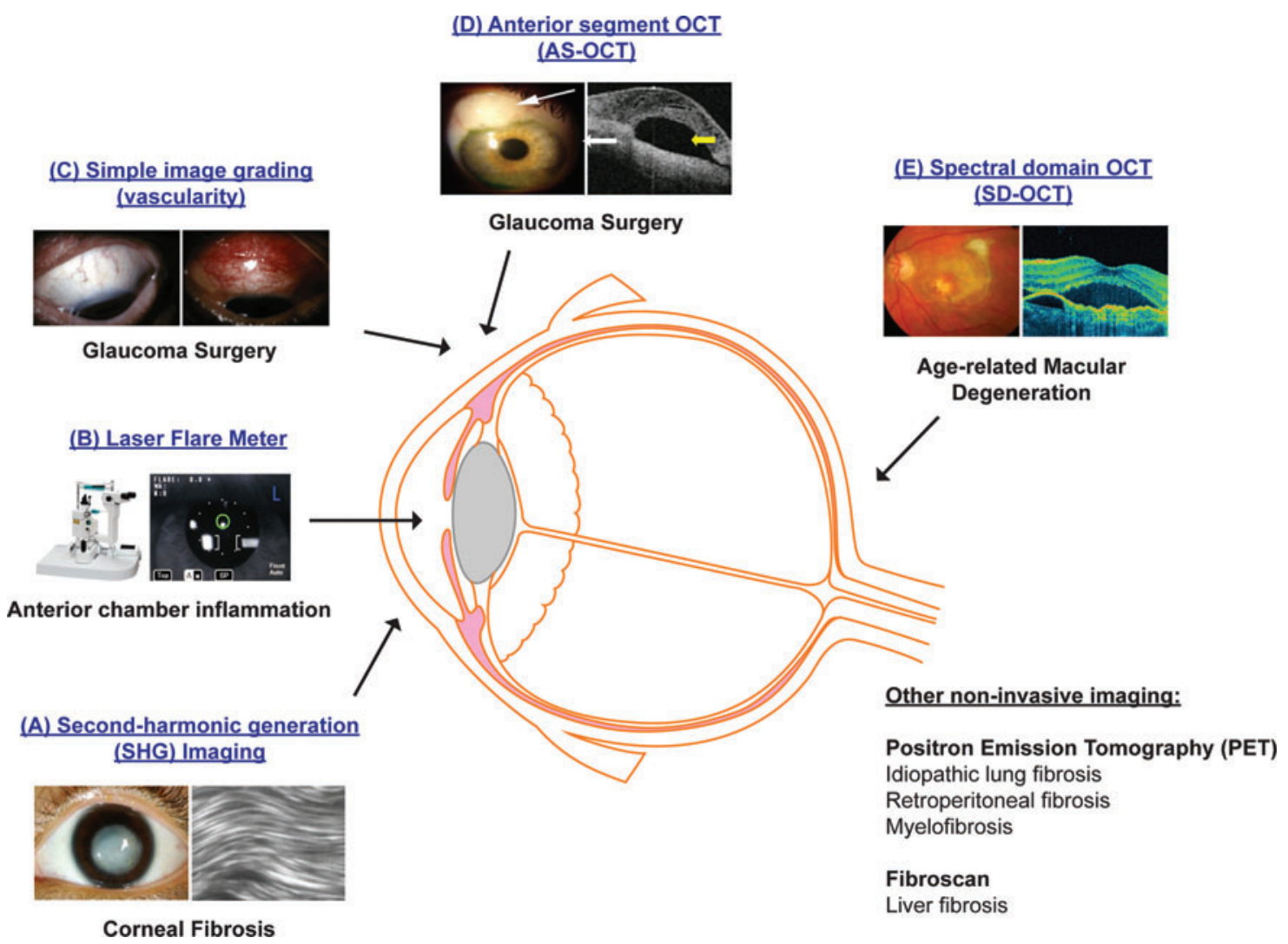

Figure 4. High-resolution noninvasive in vivo imaging represents a promising new technique to help stratify patients with different fibrotic eye diseases: (A) SHG imaging; (B) Laser flare meter; (C) Simple image grading (vascularity); (D) AS-OCT; (E) SD-OCT. SHG, second-harmonic generation; AS-OCT, anterior segment optical coherence tomography; SD-OCT, spectral domain optical coherence tomography. To see this illustration in color, the reader is referred to the web version of this article at www.liebertpub.com/wound 
of the internal ostium. Features of successful blebs were thickening of the bleb wall, ${ }^{70,71}$ a large internal fluid-filled cavity, and an extensive hyporeflective area compared to unsuccessful blebs. ${ }^{70}$

In addition, recent cataract surgery is a risk factor for failure of glaucoma filtration surgery. Using the Kowa FM-500 laser flare meter that measures the level of aqueous humour protein noninvasively in 131 patients undergoing trabeculectomy and 148 patients undergoing cataract surgery, Siriwardena et al. found that the anterior chamber flare was more prolonged after cataract surgery than after trabeculectomy. ${ }^{73}$ The release of lens crystallins and lens epithelial cells might upregulate the production of fibrogenic cytokines in the aqueous humour of patients after cataract surgery. ${ }^{74}$ The authors thus suggested that anterior chamber flare could be used as a surrogate biomarker of anterior chamber inflammation and help guide the timing of trabeculectomy in relation to cataract surgery.

Different research groups have also studied spectral-domain optical coherence tomography (SD-OCT) as a potential future tool to diagnose and follow-up patients with fibrovascular retinal diseases. Using SD-OCT, Wolff et al. found a branching retinal tubulation network emanating from a fibrovascular scar among 15 eyes of patients with neovascular AMD ${ }^{75}$ Coscas et al. also studied 38 patients with fibrovascular pigment epithelial detachment (PED) and identified a homogeneous hyperreflectivity pattern consistent with fibrous tissue using SD-OCT. ${ }^{76}$

\section{SUMMARY}

There have been significant advances in the use of genomics, proteomics, metabolomics, clinical phenotyping, and high-resolution in vivo imaging techniques to help identify and stratify the groups of patients at risk of scarring in different fibrotic eye diseases (Table 1). However, most of the studies to date have been carried out in animals or small cohorts of patients, and future research is thus needed to validate these results in large longitudinal human studies. Effective detailed clinical phenotyping, including highresolution imaging and biobanking of tissues from large patient cohorts, will also be crucial to compare putative biomarkers in ocular fibrosis to healthy controls.
As tissue biopsy can itself induce scarring in the eye, there has been growing interest in developing less invasive biomarkers such as serum or tear biomarkers and high-resolution in vivo imaging techniques. Another exciting future prospect will be to use new advances in genotyping, namely next-generation whole genome sequencing like RNA-Seq, to develop a customized gene chip in ocular fibrosis. We believe that a strong collaboration between academics, pharmaceutical, and biotech companies will also be critical for successful translation of these biomarkers to benefit patient care. The ultimate goal in the future will be to apply diagnostic and therapeutic biomarkers and to develop a more stratified approach in antifibrotic ocular therapeutics and personalized visual health.

\section{ACKNOWLEDGMENTS AND FUNDING SOURCES}

Our research is supported by the National Institute for Health Research (NIHR) Biomedical Research Centre at Moorfields Eye Hospital NHS Foundation Trust and UCL Institute of Ophthalmology, the Medical Research Council, Moorfields Trustees and Moorfields Eye Charity, the Freemasons Grand Charity, the Michael and Ilse Katz Foundation, the Helen Hamlyn Trust, and Fight for Sight (UK).

\section{AUTHOR DISCLOSURE AND GHOSTWRITING}

There has been no ghostwriting involved in the preparation of this article. 


\section{ABOUT THE AUTHORS}

Cynthia Yu-Wai-Man, MBBS, FRCOphth, is an NIHR BRC Francis Crick Institute Clinical Research Fellow and is based at the UCL Institute of Ophthalmology and the Francis Crick Institute. Her research is focused on identifying novel targets to prevent scarring in the eye and on translational antifibrosis eye research. Dr. Yu-Wai-Man is also working on potential novel biomarkers to develop a more personalized and stratified approach in antifibrotic ocular therapeutics.

\begin{abstract}
Peng Tee Khaw, PhD, FRCS, FRCP, FRCOphth, FRCPath, FRSBiol, FARVO, FMedSci, is Professor of Glaucoma and Wound healing and Director of the NIHR Biomedical Research Centre at Moorfields Eye Hospital NHS Foundation Trust and UCL Institute of Ophthalmology. For over 25 years, he has pioneered new surgical techniques and new treatments to prevent scarring and to promote regeneration of tissues after ocular surgery and disease.
\end{abstract}

\section{REFERENCES}

1. Wistow G. The NEIBank project for ocular genomics: data-mining gene expression in human and rodent eye tissues. Prog Retin Eye Res 2006;25: 43-77.

2. Wistow G, Peterson K, Gao J, Buchoff P, Jaworski C, Bowes-Rickman C, et al. NEIBank: genomics and bioinformatics resources for vision research. Mol Vis 2008;14:1327-1337

3. Vihtelic TS, Fadool JM, Gao J, Thornton KA, Hyde DR, Wistow G. Expressed sequence tag analysis of zebrafish eye tissues for NEIBank. Mol Vis 2005;11:1083-1100.

4. Tomarev SI, Wistow G, Raymond V, Dubois S, Malyukova I. Gene expression profile of the human trabecular meshwork: NEIBank sequence tag analysis. Invest Ophthalmol Vis Sci 2003;44: 2588-2596.

5. Wistow G, Bernstein SL, Wyatt MK, Ray S, Behal A, Touchman JW, et al. Expressed sequence tag analysis of human retina for the NEIBank Project: retbindin, an abundant, novel retinal cDNA and alternative splicing of other retina-preferred gene transcripts. Mol Vis 2002;8:196-204.

6. Popp MP, Liu L, Timmers A, Esson DW, Shiroma L, Meyers C, et al. Development of a microarray chip for gene expression in rabbit ocular research. Mol Vis 2007;13:164-173.

7. Esson DW, Popp MP, Liu L, Schultz GS, Sherwood MB. Microarray analysis of the failure of filtering blebs in a rat model of glaucoma filtering surgery. Invest Ophthalmol Vis Sci 2004;45:4450-4462.

8. Mahale A, Othman MW, Al Shahwan S, Al Jadaan I, Owaydha 0, Khan Z, et al. Altered expression of fibrosis genes in capsules of failed Ahmed glaucoma valve implants. PLoS One 2015; 10:e0122409

9. Hitchings RA, Grierson I. Clinico pathological correlation in eyes with failed fistulizing surgery. Trans Ophthalmol Soc U K 1983;103:84-88.

10. Chang L, Wong T, Ohbayashi M, Bunce C, Barton $K$, Ono SJ, et al. Increased mast cell numbers in the conjunctiva of glaucoma patients: a possible indicator of preoperative glaucoma surgery inflammation. Eye (Lond) 2009;23:1859-1865.
11. Chang L, Crowston JG, Cordeiro MF, Akbar AN, Khaw PT. The role of the immune system in conjunctival wound healing after glaucoma surgery. Surv Ophthalmol 2000;45:49-68.

12. Broadway DC, Grierson I, O'Brien C, Hitchings RA Adverse effects of topical antiglaucoma medication. I. The conjunctival cell profile. Arch Ophthalmol 1994;112:1437-1445.

13. Broadway DC, Grierson I, O'Brien C, Hitchings RA. Adverse effects of topical antiglaucoma medication. II. The outcome of filtration surgery. Arch Ophthalmol 1994;112:1446-1454.

14. Burton MJ, Rajak SN, Bauer J, Weiss HA, Tolbert SB, Shoo A, et al. Conjunctival transcriptome in scarring trachoma. Infect Immun 2011;79:499-511.

15. Burton MJ, Rajak SN, Hu VH, Ramadhani A, Habtamu $E$, Massae $P$, et al. Pathogenesis of progressive scarring trachoma in Ethiopia and Tanzania and its implications for disease control: two cohort studies. PLoS Negl Trop Dis 2015;9: e0003763.

16. Burton MJ, Rajak SN, Ramadhani A, Weiss HA, Habtamu E, Abera B, et al. Post-operative recurrent trachomatous trichiasis is associated with increased conjunctival expression of S100A7 (psoriasin). PLoS Negl Trop Dis 2012;6:e1985.

17. Razzaque MS, Foster CS, Ahmed AR. Role of enhanced expression of $\mathrm{m}$-CSF in conjunctiva affected by cicatricial pemphigoid. Invest Ophthalmol Vis Sci 2002;43:2977-2983.

18. Razzaque MS, Foster CS, Ahmed AR. Role of connective tissue growth factor in the pathogenesis of conjunctival scarring in ocular cicatricial pemphigoid. Invest Ophthalmol Vis Sci 2003;44: 1998-2003.

19. Razzaque MS, Foster CS, Ahmed AR. Role of collagen-binding heat shock protein 47 and transforming growth factor-beta1 in conjunctival scarring in ocular cicatricial pemphigoid. Invest Ophthalmol Vis Sci 2003;44:1616-1621.

20. Razzaque MS, Foster CS, Ahmed AR. Role of macrophage migration inhibitory factor in conjunctival pathology in ocular cicatricial pemphigoid. Invest Ophthalmol Vis Sci 2004;45:1174-1181.
21. Saw VP, Offiah I, Dart RJ, Galatowicz G, Dart JK, Daniels JT, et al. Conjunctival interleukin-13 expression in mucous membrane pemphigoid and functional effects of interleukin-13 on conjunctival fibroblasts in vitro. Am J Pathol 2009; 175:2406-2415.

22. Saw VP, Dart RJ, Galatowicz G, Daniels JT, Dart JK, Calder VL. Tumor necrosis factor-alpha in ocular mucous membrane pemphigoid and its effect on conjunctival fibroblasts. Invest Ophthalmol Vis Sci 2009;50:5310-5317.

23. Varela JC, Goldstein MH, Baker HV, Schultz GS Microarray analysis of gene expression patterns during healing of rat corneas after excimer laser photorefractive keratectomy. Invest Ophthalmol Vis Sci 2002;43:1772-1782.

24. Cao Z, Wu HK, Bruce A, Wollenberg K, Panjwani $\mathrm{N}$. Detection of differentially expressed genes in healing mouse corneas, using cDNA microarrays. Invest Ophthalmol Vis Sci 2002;43:2897-2904.

25. Saravanan C, Cao Z, Head SR, Panjwani N. Analysis of differential expression of glycosyltransferases in healing corneas by glycogene microarrays. Glycobiology 2010;20:13-23.

26. Hollborn M, Tenckhoff S, Jahn K, landiev I, Biedermann B, Schnurrbusch UE, et al. Changes in retinal gene expression in proliferative vitreoretinopathy: glial cell expression of HB-EGF. Mol Vis 2005;11:397-413.

27. Asato R, Yoshida S, Ogura A, Nakama T, Ishikawa $K$, Nakao $S$, et al. Comparison of gene expression profile of epiretinal membranes obtained from eyes with proliferative vitreoretinopathy to that of secondary epiretinal membranes. PLoS One 2013; 8:e54191.

28. Lichtinghagen R, Pietsch D, Bantel H, Manns MP Brand K, Bahr MJ. The Enhanced Liver Fibrosis (ELF) score: normal values, influence factors and proposed cut-off values. J Hepatol 2013;59:236-242.

29. Abignano G, Cuomo G, Buch MH, Rosenberg WM, Valentini G, Emery $P$, et al. The enhanced liver fibrosis test: a clinical grade, validated serum test, biomarker of overall fibrosis in systemic sclerosis. Ann Rheum Dis 2014;73:420-427. 
30. Calès $P$, Boursier J, Oberti F, Hubert I, Gallois $Y$, Rousselet MC, et al. FibroMeters: a family of blood tests for liver fibrosis. Gastroenterol Clin Biol 2008;32(6 Suppl 1):40-51.

31. Roderburg C, Urban GW, Bettermann K, Vucur M, Zimmermann H, Schmidt S, et al. MicroRNA profiling reveals a role for miR-29 in human and murine liver fibrosis. Hepatology 2011;53:209-218.

32. Roncarati R, Viviani Anselmi C, Losi MA, Papa L, Cavarretta E, Da Costa Martins P, et al. Circulating miR-29a, among other up-regulated microRNAs, is the only biomarker for both hypertrophy and fibrosis in patients with hypertrophic cardiomyopathy. J Am Coll Cardiol 2014; 63:920-927.

33. Tezel G, Thornton IL, Tong MG, Luo C, Yang X, Cai $\mathrm{J}$, et al. Immunoproteomic analysis of potential serum biomarker candidates in human glaucoma. Invest Ophthalmol Vis Sci 2012;53: 8222-8231.

34. Chong RS, Jiang YZ, Boey PY, Yu SJ, Htoon HM, Aung $T$, et al. Tear cytokine profile in medicated glaucoma patients: effect of monocyte chemoattractant protein 1 on early posttrabeculectomy outcome. Ophthalmology 2010;117: 2353-2358.

35. Dunmire JJ, Bouhenni R, Hart ML, Wakim BT, Chomyk AM, Scott SE, et al. Novel serum proteomic signatures in a non-human primate model of retinal injury. Mol Vis 2011;17:779-791.

36. Scott SE, Bouhenni RA, Chomyk AM, Dunmire JJ, Patil J, Nakamura H, et al. Anti-retinal antibodies in serum of laser-treated rabbits. Invest Ophthalmol Vis Sci 2012;53:1764-1772.

37. Kierny MR, Cunningham TD, Bouhenni RA, Edward DP, Kay BK. Generating recombinant antibodies against putative biomarkers of retinal injury. PLoS One 2015;10:e0124492.

38. Semba RD, Enghild JJ, Venkatraman V, Dyrlund TF, Van Eyk JE. The human eye proteome project: perspectives on an emerging proteome. Proteomics 2013;13:2500-2511.

39. Schiller HB, Fernandez IE, Burgstaller G, Schaab C, Scheltema RA, Schwarzmayr T, et al. Time- and compartment-resolved proteome profiling of the extracellular niche in lung injury and repair. Mol Syst Biol 2015;11:819.

40. Zhang $X, X u L$, Yin L, Oi Y, Xu Y, Han $X$, et al. Quantitative chemical proteomics for investigating the biomarkers of dioscin against liver fibrosis caused by CCl4 in rats. Chem Commun (Camb) 2015;51:11064-11067.

41. Zhong $Y$, Qin $Y$, Dang L, Jia L, Zhang Z, Wu H, et al. Alteration and localization of Glycanbinding proteins in human hepatic stellate cells during liver fibrosis. Proteomics 2015;15: 3283-3295

42. Saccà SC, Centofanti M, Izzotti A. New proteins as vascular biomarkers in primary open angle glaucomatous aqueous humor. Invest Ophthalmol Vis Sci 2012;53:4242-4253.
43. Anshu A, Price MO, Richardson MR, Segu ZM, Lai $\mathrm{X}$, Yoder $\mathrm{MC}$, et al. Alterations in the aqueous humor proteome in patients with a glaucoma shunt device. Mol Vis 2011;17:1891-1900.

44. Rosenfeld C, Price MO, Lai X, Witzmann FA, Price FWJ. Distinctive and pervasive alterations in aqueous humor protein composition following different types of glaucoma surgery. Mol Vis 2015;21: 911-918.

45. Mandal N, Lewis GP, Fisher SK, Heegaard S, Prause JU, la Cour M, et al. Protein changes in the retina following experimental retinal detachment in rabbits. Mol Vis 2011;17: 2634-2648.

46. Yu J, Peng R, Chen H, Cui C, Ba J. Elucidation of the pathogenic mechanism of rhegmatogenous retinal detachment with proliferative vitreoretinopathy by proteomic analysis. Invest Ophthalmol Vis Sci 2012;53:8146-8153.

47. Yu J, Liu F, Cui SJ, Liu Y, Song ZY, Cao H, et al. Vitreous proteomic analysis of proliferative vitreoretinopathy. Proteomics 2008;8:3667-3678.

48. Patti GJ, Yanes 0, Siuzdak G. Innovation: metabolomics: the apogee of the omics trilogy. Nat Rev Mol Cell Biol 2012;13:263-269.

49. Collino S, Martin FP, Rezzi S. Clinical metabolomics paves the way towards future healthcare strategies. Br J Clin Pharmacol 2013;75: 619-629.

50. Tokushige K, Hashimoto E, Kodama K, Tobari M, Matsushita N, Kogiso T, et al. Serum metabolomic profile and potential biomarkers for severity of fibrosis in nonalcoholic fatty liver disease. J Gastroenterol 2013;48:1392-1400.

51. Zhao Y, Yin L, Yun HZ, Peng J, Wu L, Waddell TK, et al. Metabolomic Heterogeinity of Idiopathic Pulmonary Fibrosis-A Metabolomic Study. Am J Respir Crit Care Med 2014;189:A52772.

52. Karamichos $D$, Hutcheon AE, Rich CB, TrinkausRandall V, Asara JM, Zieske JD. In vitro model suggests oxidative stress involved in keratoconus disease. Sci Rep 2014;4:4608.

53. Pastor JC, de la Rúa ER, Martín F. Proliferative vitreoretinopathy: risk factors and pathobiology. Prog Retin Eye Res 2002;21:127-144.

54. Li M, Li H, Jiang P, Liu X, Xu D, Wang F. Investigating the pathological processes of rhegmatogenous retinal detachment and proliferative vitreoretinopathy with metabolomics analysis. Mol Biosyst 2014;10:1055-1062.

55. Osborn MP, Park Y, Parks MB, Burgess LG, Uppal $\mathrm{K}$, Lee $\mathrm{K}$, et al. Metabolome-wide association study of neovascular age-related macular degeneration. PLoS One 2013;8:e72737.

56. Agudo-Barriuso M, Lahoz A, Nadal-Nicolás FM, Sobrado-Calvo P, Piquer-Gil M, Díaz-Llopis M, et al. Metabolomic changes in the rat retina after optic nerve crush. Invest Ophthalmol Vis Sci 2013;54:4249-4259.

57. Kon $\mathrm{CH}$, Asaria RH, Occleston NL, Khaw PT, Aylward GW. Risk factors for proliferative vitreor- etinopathy after primary vitrectomy: a prospective study. Br J Ophthalmol 2000;84:506-511.

58. Asaria RH, Kon CH, Bunce C, Charteris DG, Wong D, Luthert PJ, et al. How to predict proliferative vitreoretinopathy: a prospective study. Ophthalmology 2001;108:1184-1186.

59. Rajak SN, Habtamu E, Weiss $H A$, Kello $A B$, Abera B, Zerihun M, et al. The outcome of trachomatous trichiasis surgery in Ethiopia: risk factors for recurrence. PLoS Negl Trop Dis 2013; 7:e2392.

60. Meissner HH, Soo Hoo GW, Khonsary SA, Mandelkern M, Brown CV, Santiago SM. Idiopathic pulmonary fibrosis: evaluation with positron emission tomography. Respiration 2006;73:197-202.

61. Yilmaz $S$, Tan $Y Z$, Ozhan $M$, Halac $M$, Asa $S$, Sönmezoglu K. FDG PET/CT in monitoring treatment of retroperitoneal fibrosis. Rev Esp Med Nucl Imagen Mol 2012;31:338-339.

62. Derlin T, Büsche G, Kröger N. Diagnostic value of 18F-FDG-PET/CT for monitoring myelofibrosis after allogeneic stem cell transplantation. Nucl Med Rev Cent East Eur 2015;18:35-36.

63. Shen OL, Chen YJ, Wang ZM, Zhang TC, Pang WB, Shu J, et al. Assessment of liver fibrosis by Fibroscan as compared to liver biopsy in biliary atresia. World J Gastroenterol 2015;21:6931-6936.

64. Fernandez M, Trépo E, Degré D, Gustot T, Verset $L$, Demetter $P$, et al. Transient elastography using Fibroscan is the most reliable noninvasive method for the diagnosis of advanced fibrosis and cirrhosis in alcoholic liver disease. Eur J Gastroenterol Hepatol 2015:1074-1079.

65. Farid M, Morishige N, Lam L, Wahlert A, Steinert RF, Jester JV. Detection of Corneal Fibrosis by Imaging Second Harmonic-Generated Signals in Rabbit Corneas Treated with Mitomycin C after Excimer Laser Surface Ablation. Invest Ophthalmol Vis Sci 2008:49:4377-4383.

66. Han M, Zickler L, Giese G, Walter M, Loesel FH, Bille JF. Second-harmonic imaging of cornea after intrastromal femtosecond laser ablation. J Biomed Opt 2004;9:760-766.

67. Teng SW, Tan HY, Sun Y, Lin SJ, Lo W, Hsueh CM, et al. Multiphoton fluorescence and secondharmonic-generation microscopy for imaging structural alterations in corneal scar tissue in penetrating full-thickness wound. Arch Ophthalmol 2007;125: 977-978.

68. Wells AP, Crowston JG, Marks J, Kirwan JF, Smith G, Clarke JC, et al. A pilot study of a system for grading of drainage blebs after glaucoma surgery. J Glaucoma 2004;13:454-460.

69. Jung KI, Lim SA, Park HY, Park CK. Visualization of blebs using anterior-segment optical coherence tomography after glaucoma drainage implant surgery. Ophthalmology 2013;120:978-983.

70. Kawana K, Kiuchi T, Yasuno $Y$, Oshika T. Evaluation of trabeculectomy blebs using 3dimensional cornea and anterior segment optical coherence tomography. Ophthalmology 2009;116: 848-855. 
71. Singh $M$, Chew PT, Friedman DS, Nolan WP, See JL, Smith SD, et al. Imaging of trabeculectomy blebs using anterior segment optical coherence tomography. Ophthalmology 2007;114: 47-53.

72. Singh $M$, Aung T, Friedman DS, Zheng C, Foster PJ, Nolan WP, et al. Anterior segment optical coherence tomography imaging of trabeculectomy blebs before and after laser suture lysis. Am J Ophthalmol 2007;143:873-875

73. Siriwardena D, Kotecha A, Minassian D, Dart JK, Khaw PT. Anterior chamber flare after trabeculectomy and after phacoemulsification. Br J Ophthalmol 2000;84:1056-1057.

74. Allen JB, Davidson MG, Nasisse MP, Fleisher LN McGahan MC. The lens influences aqueous humor levels of transforming growth factor-beta 2. Graefes Arch Clin Exp Ophthalmol 1998;236:305311.

75. Wolff B, Matet A, Vasseur V, Sahel JA, MaugetFaÿsse M. En face OCT imaging for the diagnosis of outer retinal tubulations in age-related macular degeneration. J Ophthalmol 2012;2012 542417.

76. Coscas F, Coscas G, Querques G, Massamba N Querques L, Bandello F, et al. En face enhanced depth imaging optical coherence tomography of fibrovascular pigment epithelium detachment. Invest Ophthalmol Vis Sci 2012; 53:4147-4151.

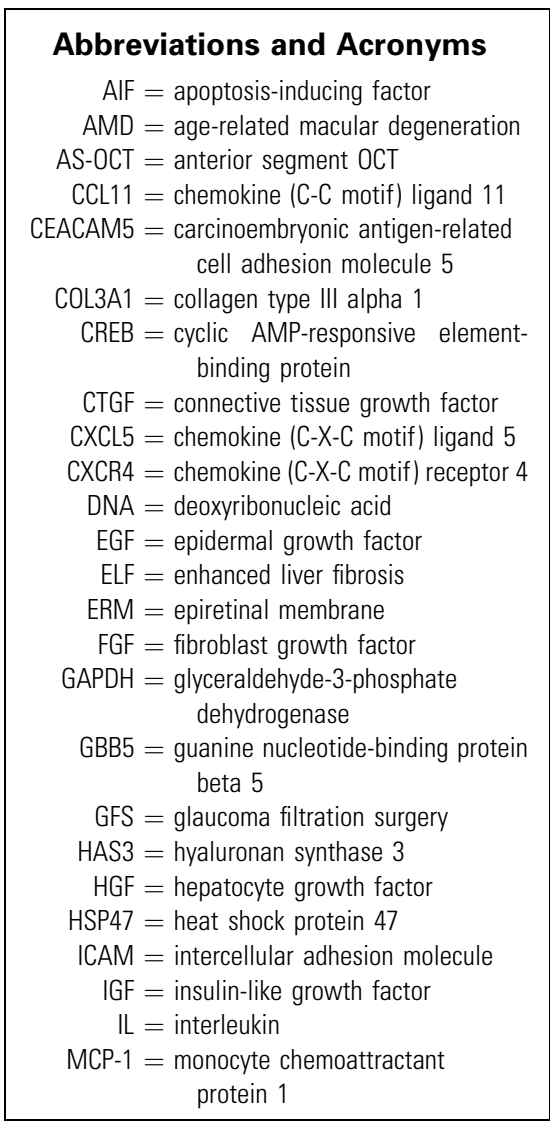

